\title{
Las Derrumbadas Volcano: Gas Geochemistry of Promising Geothermal Resources in Puebla, \\ Mexico
}

Typhaine Tual ${ }^{1}$, Snorri Gudbrandsson ${ }^{2}$, Elodie Muller ${ }^{3}$, Marie-Noëlle Guilbaud ${ }^{4}$, Carole Cordier ${ }^{5}$, Manuel Moreira $^{3}$, Laurent Escaré ${ }^{1}$

1typhaine.tual@storengy.com, ${ }^{2}$ snorri@rg.is,

${ }^{3}$ emuller@ipgp.fr, ${ }^{4}$ marie@geofisica.unam.mx 5 carole.cordier@univ-grenoble-alpes.fr, ${ }^{6}$

moreira@ipgp.fr, ${ }^{7}$ laurent.escare@,storengy.com

Las Derrumbadas is a geothermal prospect located in the Mexican state of Puebla. Las Derrumbadas is a rhyolitic complex of twin domes in the eastern part of the TransMexican Volcanic Belt. The volcano breaks through the sedimentary basin of Serdán-Oriental, composed of clastic and Mesozoic calcic layers reaching a thickness of 1000 meters. The Libres Oriental aquifer circulates in these sedimentary layers. The Serdán-Oriental basin is dotted with other volcanoes and numerous maars. Recent geochronological data suggest that Las Derrumbadas is merely 2000 years old. Fumaroles as well as intensive hydrothermal alteration at the summit of Las Derrumbadas indicate the presence of a high enthalpy geothermal system.

In 2018, gas samples were collected from these fumaroles for chemical, noble gas and isotopic analyses. The objective was to determine the characteristics of the steam from the fumaroles as well as the origin of the associated gases, besides getting a first idea of the reservoir temperature. Gases are characterized by a high concentration of $\mathrm{CO}_{2}$ and $\mathrm{CH}_{4}$. No $\mathrm{H}_{2} \mathrm{~S}$ has been detected in the fluids from the area. The isotopic compositions of gases sampled in Las Derrumbadas show a magmatic signature suggesting the presence of a deep, still active heat source. Gases are highly enriched in Helium with $\mathrm{R} / \mathrm{Ra}$ which indicating the influence of a high mantellic contribution. The $\delta^{13} \mathrm{C}_{\mathrm{CO} 2}$ and $\delta \mathrm{D}_{\mathrm{CH} 4}$ compositions also suggest a hydrothermal origin without Mesozoic sedimentary contribution. However, isotopic values of the condensate, $\delta \mathrm{D}_{\mathrm{H} 2 \mathrm{O}}$ (and $\delta^{18} \mathrm{O}_{\mathrm{H} 2 \mathrm{O}}$ show that water was freshly infiltered.

The absence of sulfur in the fumaroles constitutes an anomaly for this subduction context because gases from rhyolitic magma usually show very high levels of $\mathrm{H}_{2} \mathrm{~S}$, but it can be explained in two ways.

The geological and geochemical characteristics of Las Derrumbadas indicate the presence of a high temperature geothermal system. Gas geothermometry suggests temperatures higher than $200{ }^{\circ} \mathrm{C}$. 